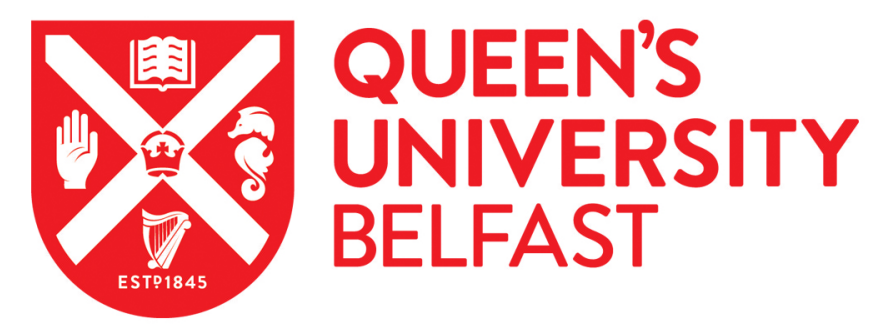

\title{
Change in type-2 biomarkers and related cytokines with prednisolone in uncontrolled severe oral corticosteroid dependent asthmatics: an interventional open-label study
}

Busby, J., Holweg, C., Chai, A., Bradding, P., Cai, F., Chaudhuri, R., Mansur, A., Lordan, J., Matthews, J. G., Menzies-Gow, A., Niven, R., Staton, T., Heaney, L. G., \& Medical Research Council UK Refractory Asthma Stratification Programme (RASP-UK) (2019). Change in type-2 biomarkers and related cytokines with prednisolone in uncontrolled severe oral corticosteroid dependent asthmatics: an interventional open-label study. Thorax, 74(8), 806-809. https://doi.org/10.1136/thoraxjnl-2018-212709

Published in:

Thorax

Document Version:

Peer reviewed version

Queen's University Belfast - Research Portal:

Link to publication record in Queen's University Belfast Research Portal

\section{Publisher rights}

Copyright 2019 the authors.

This manuscript is distributed under a Creative Commons Attribution-NonCommercial License (https://creativecommons.org/licenses/by$\mathrm{nc} / 4.0 /$ ), which permits use, distribution and reproduction for non-commercial purposes, provided the author and source are cited.

\section{General rights}

Copyright for the publications made accessible via the Queen's University Belfast Research Portal is retained by the author(s) and / or other copyright owners and it is a condition of accessing these publications that users recognise and abide by the legal requirements associated with these rights.

\section{Take down policy}

The Research Portal is Queen's institutional repository that provides access to Queen's research output. Every effort has been made to ensure that content in the Research Portal does not infringe any person's rights, or applicable UK laws. If you discover content in the Research Portal that you believe breaches copyright or violates any law, please contact openaccess@qub.ac.uk. 
Title: Change in type-2 biomarkers and related cytokines with prednisolone in uncontrolled severe oral corticosteroid dependent asthmatics: an interventional open-label study

Authors: John Busby ${ }^{1}$, Cecile Holweg ${ }^{2}$, Akiko Chai ${ }^{2}$, Peter Bradding ${ }^{3}$, Fang $\mathrm{Cai}^{2}$, Rekha Chaudhuri ${ }^{4}$, Adel Mansur ${ }^{5}$, James Lordan ${ }^{7}$, John G Matthews², Andrew Menzies-Gow ${ }^{6}$, Rob Niven ${ }^{8}$, Tracy Staton ${ }^{2}$, Liam G Heaney ${ }^{1}$ in collaboration with the UK Refractory Asthma Stratification Programme (RASP-UK).

${ }^{1}$ Queen's University Belfast, ${ }^{2}$ Genentech Inc., ${ }^{3}$ University of Leicester, ${ }^{4}$ Gartnavel General Hospital and University of Glasgow, ${ }^{5}$ University of Birmingham, ${ }^{6}$ Royal Brompton \& Harefield NHS Foundation Trust, ${ }^{7}$ Freemans Hospital Newcastle upon Tyne Hospitals NHS Foundation Trust, ${ }^{8}$ The University of Manchester

Corresponding Author: Professor Liam G Heaney, I.heaney@qub.ac.uk, +44 (0) 2890976376 


\section{Abstract}

Type-2 biomarkers and related cytokines (IL-5, IL-13), lung function and asthma symptoms were measured in 44 poorly-controlled severe oral corticosteroid (OCS)-dependent asthmatics for up to 88 days after a seven-day prednisolone boost $(0.5 \mathrm{mg} / \mathrm{kg})$. High-dose OCS reduced median blood eosinophils (-60cells/ $\mu \mathrm{l} ; 95 \% \mathrm{Cl}$ : -140, -10), periostin (-8.4ng/ml; -11.6, -2.8), FeNO (-19.0ppb; -28.5, 4.0), IL-5 $(-0.17 \mathrm{pg} / \mathrm{ml} ;-0.28,-0.08)$ and IL-13 $(-0.15 \mathrm{pg} / \mathrm{ml} ;-0.27,-0.03)$. There were small improvements in mean $\mathrm{FEV}_{1}(0.16 \mathrm{~L} ; 0.05,0.27)$ and ACQ-7 score $(0.3 ; 0.0,0.7)$. Study measures returned to baseline one month post-intervention. Following rescue OCS, one month is sufficient before using type-2 biomarkers to guide long-term treatment. 


\section{Introduction}

The effect of high-dose oral corticosteroids in OCS-dependent asthmatics is currently unknown. This group is important as they represent a large proportion of the severe asthma population, are patients with multiple corticosteroid-associated morbidities, and drive much of the healthcare cost of asthma. ${ }^{1}$ Type-2 biomarkers are used to guide treatment for novel biologic therapies, making it important to understand the longitudinal stability of their profile following high-dose OCS. The aims of this study were to examine the trajectory of the type-2 biomarker profile in severe OCSdependent asthmatics after additional high-dose OCS. 


\section{Methods}

Participants aged between 12 and 75 with well characterised severe uncontrolled asthma were recruited from UK Severe Registry centres between July 2013 and February 2014. All patients were adherent with a maintenance dose of at least $10 \mathrm{mg}$ prednisolone for at least six months prior to study initiation based on prednisolone/cortisol levels. Full details of study inclusion criteria are given in the online supplement. The study received Ethical Approval from National Research Ethics Service East of England (Ref: 13/EE/0099) and was registered on ClincalTrials.Gov (https://clinicaltrials.gov/ct2/show/NCT01948401).

Subjects were offered a 7-day OCS escalation $(0.5 \mathrm{mg} / \mathrm{kg})$ and invited to attend four follow-up visits 1 (visit 2), 32 (visit 3), 60 (visit 4) and 88 (visit 5) days post-intervention. Patient outcomes including type-2 biomarkers (blood eosinophils, FeNO, serum periostin), cytokines (serum IL-5, IL-13), spirometry ( $\left.\mathrm{FEV}_{1}, \mathrm{FVC}\right)$, and patient-reported symptoms (ACQ-7) were collected at baseline and during follow-up visits (see tables e1, e2 online supplement). Patients receiving additional rescue OCS for an asthma exacerbation during follow-up were excluded from future study visits.

Descriptive data is presented using the mean (SD) or median (IQR). For normally distributed variables mean change from baseline was calculated for each follow-up visit, and paired t-tests used to formally test for differences. For non-normally distributed variables, median difference from baseline were calculated (with bootstrapped 95\% confidence intervals), and the Wilcoxon signedrank test used to test for differences. We conducted separate short-term (visit, visit 2 and visit 3 ) and long-term (all study visits) analysis. For each outcome, patients with missing data at baseline, visit 2 or visit 3 where excluded from the short-term analysis. Similarly, patients with missing data at any study visit were excluded from the long-term analysis. 


\section{Results}

Forty-four subjects were recruited and 17 completed long-term follow-up (6 did not consent to longterm follow-up, 2 did not attend study visits, 19 required rescue steroids; Figure e1). Cohort details are given in Table 1.

In the short-term analysis, there were median decreases of 60 cells $/ \mu \mathrm{l}(95 \% \mathrm{Cl}: 10,140 ; p=0.004), 8.4$ $\mathrm{ng} / \mathrm{ml}(95 \% \mathrm{Cl}: 2.8,11.6 ; \mathrm{p}<0.001)$ and $19.0 \mathrm{ppb}(95 \% \mathrm{Cl}: 4.0,28.5 ; \mathrm{p}<0.001)$ between baseline and visit 2 for blood eosinophils, serum periostin and FeNO respectively (Table 2, figure e2). Serum IL-5 and IL-13 concentrations were reduced between baseline and visit 2 by $0.17 \mathrm{pg} / \mathrm{ml}(95 \% \mathrm{Cl}: 0.08$, $0.28 ; \mathrm{p}=0.002)$ and $0.15 \mathrm{pg} / \mathrm{ml}(95 \% \mathrm{Cl}: 0.03,0.27 ; \mathrm{p}=0.002)$ respectively. Blood eosinophils, serum periostin, FeNO and serum IL-5 concentration returned to baseline levels by visit 3 (visit 4 for cytokines), although serum IL-13 was slightly higher $(0.07 \mathrm{pg} / \mathrm{ml} ; 95 \% \mathrm{Cl}:-0.01,0.33 ; \mathrm{p}=0.028)$ than baseline (Table 2, figure e2) at this point. $\mathrm{FEV}_{1}(160 \mathrm{ml} ; 95 \% \mathrm{Cl}: 50,270 ; \mathrm{p}=0.005)$ and FVC (160ml; 95\% Cl: 40, 280; $p=0.009$ ) showed small improvements after high-dose OCS (Table 2, figure e2), but were close to baseline by visit 3 .

These short-term changes were replicated in patients with complete data to study end, although standard errors were noticeably larger due to a smaller sample size. Each of the study measures was close to baseline by visit 4, and remained relatively stable until visit 5 (Figure 1, table e3). 


\section{Discussion}

Seven days of high-dose OCS treatment significantly reduced type-2 biomarker and related cytokine levels, but was associated with only small improvements in lung function and patient-reported symptoms. In general, all study measures had returned to baseline levels one month postintervention, and remained stable until three months post-intervention.

To our knowledge, this is the first study to investigate the effect of high-dose OCS in severe OCSdependent asthmatics. Our data concurs with studies of broader severe asthma populations which reported significant reductions in blood eosinophils ${ }^{2-4}$ and FeNO ${ }^{2-4}$ after high-dose OCS. Changes in serum type-2 cytokine levels have been variably reported. ${ }^{25}$ Increased $\mathrm{FEV}_{1}{ }^{2-9}$, and improved ACQ scores ${ }^{34}$ have been reported after high-dose OCS in patients not on maintenance steroids.

Our results suggest that, after rescue steroids, clinicians should wait one month before using type-2 biomarkers to guide treatment in OCS-dependent asthmatics. This is particularly relevant for patients where type-2 biomarkers are used to guide treatment for biologic therapies, where failure to account for recent high-dose OCS could lead to effective therapies being unnecessarily withheld. The high exacerbation rate observed within our study suggests that the issue of how to interpret type-2 biomarker results in light of recent rescue steroids is commonly faced in routine clinical practice. Our data confirm that high-dose OCS inhibit both the IL-5 and IL-13 pathways, but despite significant reductions in type-2 inflammation, patients had significant residual impaired lung function and high symptoms scores. This suggests that broad targeting of the type-2 cytokine axis may leave significant unmet clinical need.

The study has some potential weaknesses as it is observational and hence open to confounding. The first post-intervention follow-up was one month after the intervention period, therefore a more precise timing of biomarker levels returning to baseline prior to this time-point could not be determined. However, type-2 biomarkers were decreased two weeks after prednisolone treatment for acute exacerbation, suggesting that shorter time periods are unlikely to be sufficient. ${ }^{10}$ We necessarily excluded patients who had additional rescue OCS to treat exacerbations during follow-up which reduced the sample size in our long-term analysis and may have hindered generalisability.

In summary, type-2 biomarker and serum cytokine levels are significantly suppressed after high-dose OCS treatment in OCS-dependent asthmatics, but return to baseline levels after one month. 
Following rescue steroids, one month is a sufficient time period before using type- 2 biomarkers to guide long-term treatment decisions. 


\section{References}

1. O'Neill S, Sweeney J, Patterson CC, et al. The cost of treating severe refractory asthma in the UK: an economic analysis from the British Thoracic Society Difficult Asthma Registry. Thorax 2015;70(4):376-8. doi: 10.1136/thoraxjnl-2013-204114 [published Online First: 2014/06/12]

2. Sousa AR, Marshall RP, Warnock LC, et al. Responsiveness to oral prednisolone in severe asthma is related to the degree of eosinophilic airway inflammation. Clinical and experimental allergy : journal of the British Society for Allergy and Clinical Immunology 2017;47(7):890-99. doi: 10.1111/cea.12954 [published Online First: 2017/05/12]

3. Oishi K, Hirano T, Suetake R, et al. A trial of oral corticosteroids for persistent systemic and airway inflammation in severe asthma. Immunity, inflammation and disease 2017;5(3):261-64. doi: 10.1002/iid3.166 [published Online First: 2017/05/06]

4. Matsunaga K, Hirano T, Akamatsu K, et al. Predictors for identifying the efficacy of systemic steroids on sustained exhaled nitric oxide elevation in severe asthma. Allergology international : official journal of the Japanese Society of Allergology 2013;62(3):359-65. doi: 10.2332/allergolint.12-OA-0530 [published Online First: 2013/07/25]

5. Bentley AM, Hamid Q, Robinson DS, et al. Prednisolone treatment in asthma. Reduction in the numbers of eosinophils, T cells, tryptase-only positive mast cells, and modulation of IL-4, IL5 , and interferon-gamma cytokine gene expression within the bronchial mucosa. American journal of respiratory and critical care medicine 1996;153(2):551-6. doi: 10.1164/ajrccm.153.2.8564096 [published Online First: 1996/02/01]

6. Djukanovic R, Homeyard S, Gratziou C, et al. The effect of treatment with oral corticosteroids on asthma symptoms and airway inflammation. American journal of respiratory and critical care medicine 1997;155(3):826-32. doi: 10.1164/ajrccm.155.3.9117012 [published Online First: 1997/03/01]

7. Chakir J, Hamid Q, Bosse $M$, et al. Bronchial inflammation in corticosteroid-sensitive and corticosteroid-resistant asthma at baseline and on oral corticosteroid treatment. Clinical and experimental allergy : journal of the British Society for Allergy and Clinical Immunology 2002;32(4):578-82. [published Online First: 2002/04/26]

8. Fukakusa M, Bergeron C, Tulic MK, et al. Oral corticosteroids decrease eosinophil and CC chemokine expression but increase neutrophil, IL-8, and IFN-gamma-inducible protein 10 expression in asthmatic airway mucosa. The Journal of allergy and clinical immunology 2005;115(2):280-6. doi: 10.1016/j.jaci.2004.10.036 [published Online First: 2005/02/08]

9. Kupczyk M, Haque S, Middelveld RJ, et al. Phenotypic predictors of response to oral glucocorticosteroids in severe asthma. Respiratory medicine 2013;107(10):1521-30. doi: 10.1016/j.rmed.2013.07.014 [published Online First: 2013/09/03]

10. Semprini R, Shortt N, Ebmeier S, et al. Change in biomarkers of type-2 inflammation following severe exacerbations of asthma. Thorax 2018 doi: 10.1136/thoraxjnl-2018-211657 


\section{Figure Legends}

Figure 1: Trajectories of type-2 biomarkers and cytokines, patient reported outcomes (ACQ and $A Q L Q$ ) and lung function ( $F E V_{1}$ and FVC) over serial study visits - subjects with missing data at any of the study visit, or who required additional rescue corticosteroids for exacerbation in addition to the high-dose OCS between baseline visit and study 2 were excluded. Data are shown as median or mean difference (with 95\% confidence intervals) as appropriate. 


\section{Footnotes}

Contributions: JB conducted the statistical analysis and drafted the manuscript. $\mathrm{CH}, \mathrm{AC}, \mathrm{FC}, \mathrm{JGW}, \mathrm{TS}$ and LH contributed to the planning and conduct of the clinical trial including assay development and interpretation of data, and critical review of the study. PB, RC, AM, JL, AM-G and RN contributed to the planning and conduct of the clinical trial, interpretation of data and critical review of the study. All authors reviewed and approved the final version of the manuscript. JB acts as study guarantor.

Funding: Data were generated and supplied by Genentech Inc. Funding for the analysis was supplied by the Medical Research Council (MR/M016579/1).

Conflict of Interest: CH, AC, JGM, TS are employees of Genentech Inc., a Member of the Roche Group and own Roche stock. RC has attended Advisory Board Meetings for AstraZeneca, GSK, Novartis and Teva and been a speaker at meetings for AstraZeneca. She has attended conferences supported by Boehringer, Teva, AstraZeneca and received educational grants from Novartis and Aerocrine. AM received personal and department funds for talks and advisory board meetings and was sponsored to attend national and international conferences from pharmaceutical companies that include GlaxoSmithKline, Astra Zeneca, Novartis, NAPP, Boehringer Ingelheim, Roche, Chiesi. AM-G has attended advisory boards with GlaxoSmithKline, Novartis, AstraZeneca, Boehringer Ingelheim and Teva. He has received speaker fees from Novartis, AstraZeneca, Vectura, Boehringer Ingelheim, Sanofi and Teva. He has participated in research with Hoffman La Roche, GlaxoSmithKline, Boehringer Ingelheim and Astra Zeneca. He has attended international conferences with Teva and Boehringer Ingelheim and has consultancy agreements with AstraZeneca, Sanofi and Vectura. RN has received an unrestricted grant of $£ 10,000$ from Novartis in 2010 towards development of clinical services at the University Hospital of South Manchester. He has run preceptorship programmes in 2015 and 2016. These programmes have resulted in payment to the University Hospital of south Manchester for amounts not exceeding $£ 10,000$. He has also performed lecturing at Pharmaceutically sponsored meetings for the following pharmaceutical companies in the last 3 years:- Astra Zeneca $(<£ 1,000)$, Boehringer Ingelheim $(<£ 2,000)$ Boston scientific $(<£ 5,000)$ Chiesi $(<£ 1,000)$, Novartis $<£ 10,000$, Napp $(<f 2,000)$, Teva $(<£ 2,000)$. He has sat on advisory boards for the following companies in the last 3 years, (Astra Zeneca, Boehringer Ingelheim, Boston scientific, Chiesi, GSK, Novartis Vectura and Teva), receiving reimbursement not exceeding $£ 5,000$ per company. He has received sponsorship support to attend international academic meetings from Astra Zeneca, Boehringer ingelheim, Novartis, GSK, Chiesi and TEVA. Dr Niven, (or any members of his family) has no shares or any pecuniary interest in any pharmaceutical industry and has no shareholdings or dividends and is not a paid consultant for 
any company. LGH is Academic Lead for the Medical Research Council Stratified Medicine UK Consortium in Severe Asthma which involves industrial partnerships with a number of pharmaceutical companies. The remaining authors declare that they have no competing interests.

Ethics approval: National Research Ethics Service East of England (Cambridge South Committee Ref: 13/EE/0099)

Trial Registration: ClincalTrials.Gov (https://clinicaltrials.gov/ct2/show/NCT01948401) 


\section{Tables and Figures}

Table 1: Baseline characteristics of the study population.

Data are shown as median (IQR), mean (SD) or $\mathrm{n}(\%)$ as appropriate.

\begin{tabular}{|c|c|}
\hline Number of Patients & 44 \\
\hline \multicolumn{2}{|l|}{ Demographics } \\
\hline Age (years, Mean [SD]) & $52.9(10.5)$ \\
\hline $0-20$ & $0(0 \%)$ \\
\hline $21-40$ & $4(9.1 \%)$ \\
\hline $41-60$ & $29(65.9 \%)$ \\
\hline $60+$ & $10(22.7 \%)$ \\
\hline Missing & $1(2.3 \%)$ \\
\hline Female $(n, \%)$ & $24(54.5 \%)$ \\
\hline Body mass index (mean [SD]) & $30.4(4.4)$ \\
\hline ACQ-7 score (mean [SD]) & $3.2(1.2)$ \\
\hline AQLQ (mean [SD]) & $3.8(1.3)$ \\
\hline \multicolumn{2}{|l|}{ Asthma History / treatment } \\
\hline Exacerbations in prior year & $5.5(2.5,8.0)$ \\
\hline 0 & $2(4.5 \%)$ \\
\hline 1 & $5(11.4 \%)$ \\
\hline $2-3$ & $8(18.2 \%)$ \\
\hline $4-6$ & $17(38.6 \%)$ \\
\hline $7-10$ & 5 (11.4\%) \\
\hline $11+$ & 7 (15.9\%) \\
\hline Hospitalisations in prior year & $0.0(0.0,1.0)$ \\
\hline 0 & $23(52.3 \%)$ \\
\hline 1 & $11(25.0 \%)$ \\
\hline $2-3$ & $8(18.2 \%)$ \\
\hline $4+$ & $2(4.5 \%)$ \\
\hline Immunotherapy ever (n, \%) & $3(6.8 \%)$ \\
\hline Intubated ever (n, \%) & $4(9.1 \%)$ \\
\hline Maintenance OCS dose (median, IQR) & $10(10,20)$ \\
\hline BDP equivalent ICS dose (median, IQR) & $2000(2000,2000)$ \\
\hline \multicolumn{2}{|l|}{ Lung Function } \\
\hline $\mathrm{FEV}_{1}$ (Litres, mean [SD]) & $1.91(0.54)$ \\
\hline$\% \mathrm{FEV}_{1}$ Predicted (mean [SD]) & $62.4(16.8)$ \\
\hline FVC (Litres, mean [SD]) & $3.01(0.71)$ \\
\hline \% FVC Predicted (mean [SD]) & $76.9(15.2)$ \\
\hline \multicolumn{2}{|l|}{ Type-2 Biomarkers } \\
\hline Blood Eosinophils (cells $/ \mu$ l) & $200(120,360)$ \\
\hline Serum Periostin (ng/mL) & $49.4(39.3,56.3)$ \\
\hline FeNO (ppb) & $47.5(18.0,66.0)$ \\
\hline IGE (IU/mL) & $101(22,255)$ \\
\hline \multicolumn{2}{|l|}{ Type-2 Cytokines in serum } \\
\hline IL-5 Concentration (pg/ml) & $0.32(0.13,0.69)$ \\
\hline IL-13 Concentration (pg/ml) & $0.46(0.21,0.75)$ \\
\hline
\end{tabular}


Table 2: Short-term change in study measures between baseline visit (visit 1) and 1 day (visit 2) and 32 days (visit 3) after completing 7 days of high-dose oral corticosteroids $(0.5 \mathrm{mg} / \mathrm{kg})$ - subjects with missing data at any of the short-term visits, or who required additional rescue corticosteroids for exacerbation in addition to the study intervention were excluded. Data are shown as median (IQR) or mean (SD) as appropriate.

\begin{tabular}{|c|c|c|c|c|c|c|c|c|}
\hline \multirow[b]{2}{*}{ Measure } & \multirow[b]{2}{*}{ Count } & \multirow[b]{2}{*}{$\begin{array}{c}\text { Baseline } \\
\text { Absolute Value }\end{array}$} & \multicolumn{3}{|c|}{ Visit 2 (1 day post-intervention) } & \multicolumn{3}{|c|}{ Visit $3^{\mathrm{a}}$ (32 days post-intervention) } \\
\hline & & & $\begin{array}{c}\text { Absolute } \\
\text { Value }\end{array}$ & $\begin{array}{l}\text { Difference } \\
(95 \% \mathrm{Cl})\end{array}$ & $\mathbf{P}$ & $\begin{array}{c}\text { Absolute } \\
\text { Value }\end{array}$ & $\begin{array}{c}\text { Difference } \\
(95 \% \mathrm{Cl})\end{array}$ & $\mathbf{P}$ \\
\hline \multicolumn{9}{|l|}{ Type-2 Biomarkers } \\
\hline Blood Eosinophils $(\mathrm{N} / \mathrm{ul})^{\mathrm{b}}$ & 27 & $190(100,290)$ & $130(100,170)$ & $-60(-140,-10)$ & 0.004 & $180(110,400)$ & $-10(-85,135)$ & 0.895 \\
\hline Serum Periostin $(\mathrm{ng} / \mathrm{ml})^{\mathrm{b}}$ & 29 & $48.2(39.3,55.1)$ & $39.8(34.8,50.5)$ & $-8.4(-11.6,-2.8)$ & $<0.001$ & $47.5(41.8,57.7)$ & $-0.7(-4.2,5.3)$ & 0.469 \\
\hline FeNO $(\mathrm{ppb})^{\mathrm{b}}$ & 27 & $49.0(18.0,77.0)$ & $30.0(17.0,46.0)$ & $-19.0(-28.5,-4.0)$ & $<0.001$ & $37.0(22.0,56.0)$ & $-12.0(-21.0,5.0)$ & 0.139 \\
\hline \multicolumn{9}{|l|}{ Type-2 Cytokines in serum } \\
\hline IL-5 Concentration $(\mathrm{pg} / \mathrm{ml})^{\mathrm{b}}$ & 18 & $0.22(0.11,0.54)$ & $0.05(0.00,0.14)$ & $-0.17(-0.28,-0.08)$ & 0.002 & $0.27(0.16,0.49)$ & $0.05(-0.07,0.28)$ & 0.913 \\
\hline IL-13 Concentration $(\mathrm{pg} / \mathrm{ml})^{\mathrm{b}}$ & 17 & $0.31(0.19,0.50)$ & $0.16(0.11,0.22)$ & $-0.15(-0.27,-0.03)$ & 0.002 & $0.38(0.32,0.82)$ & $0.07(-0.01,0.33)$ & 0.028 \\
\hline \multicolumn{9}{|l|}{ Lung Function } \\
\hline $\mathrm{FEV}_{1}$ (litres) $^{\mathrm{c}}$ & 28 & $1.98(0.55)$ & $2.14(0.61)$ & $0.16(0.05,0.27)$ & 0.005 & $1.95(0.55)$ & $-0.03(-0.15,0.09)$ & 0.607 \\
\hline $\mathrm{FEV}_{1}(\% \text { Predicted })^{\mathrm{c}}$ & 28 & $64.0(17.5)$ & $69.2(18.4)$ & $5.2(1.8,8.5)$ & 0.004 & $63.6(18.8)$ & $-0.4(-4.1,3.4)$ & 0.848 \\
\hline FVC (litres) ${ }^{c}$ & 28 & $3.11(0.70)$ & $3.28(0.75)$ & $0.16(0.04,0.28)$ & 0.009 & $3.06(0.73)$ & $-0.06(-0.21,0.10)$ & 0.460 \\
\hline FVC $(\% \text { Predicted })^{c}$ & 28 & $78.3(14.4)$ & $82.1(14.2)$ & $3.9(1.1,6.7)$ & 0.009 & $77.0(15.7)$ & $-1.2(-5.0,2.6)$ & 0.516 \\
\hline \multicolumn{9}{|l|}{ Patient reported outcomes } \\
\hline ACQ Score ${ }^{c}$ & 30 & $3.0(1.1)$ & $2.6(1.2)$ & $-0.3(-0.7,0.0)$ & 0.045 & $3.2(1.1)$ & $0.2(-0.0,0.4)$ & 0.090 \\
\hline AQLQ Score ${ }^{c}$ & 30 & $3.9(1.3)$ & $4.1(1.4)$ & $0.2(0.0,0.4)$ & 0.095 & $4.0(1.3)$ & $0.1(-0.1,0.2)$ & 0.514 \\
\hline
\end{tabular}

a Except IL-5 and IL-13 where visit 4 (60 days post-intervention) is presented.

${ }^{\mathrm{b}}$ Median (inter-quartile range)

c Mean (standard deviation) 
Figure 1: Trajectories of type-2 biomarkers and cytokines, patient reported outcomes (ACQ and $A Q L Q$ ) and lung function (FEV 1 and FVC) over serial study visits - subjects with missing data at any of the study visit, or who required additional rescue corticosteroids for exacerbation in addition to the high-dose OCS between baseline visit and study 2 were excluded. Data are shown as median or mean difference (with $95 \%$ confidence intervals) as appropriate. Significant at the $5 \%\left({ }^{*}\right)$ or $1 \%\left({ }^{* *}\right)$ level.

\section{Type-2 Biomarkers}

Blood Eosinophils (N/ul, $n=14$ )

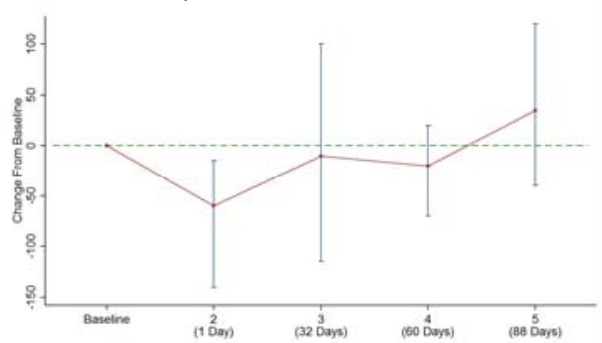

FeNO $(p p b, n=13)$

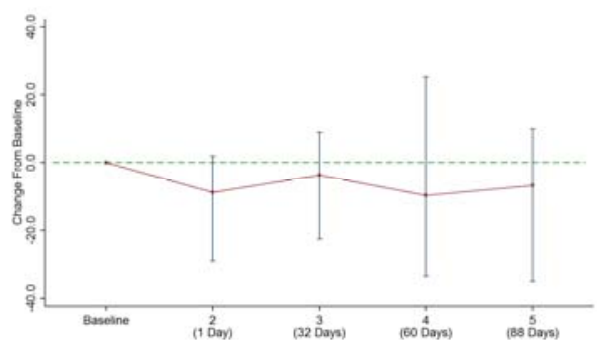

\section{Type-2 Cytokines}

Serum IL-5 Concentration ( $\mathrm{pg} / \mathrm{ml}, \mathrm{n}=18$ )

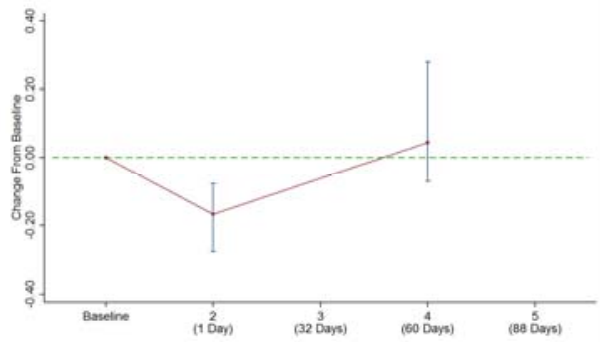

\section{Lung Function}

$\mathrm{FEV}_{1}$ (litres, $\mathrm{n}=16$ )

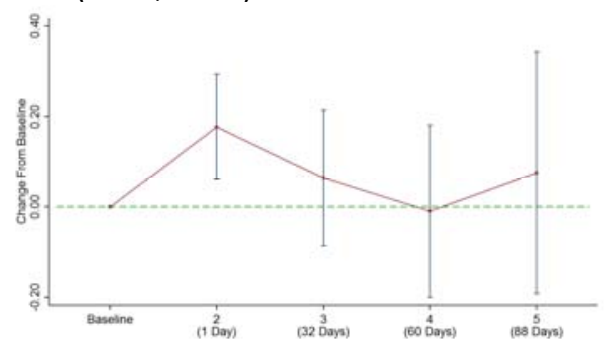

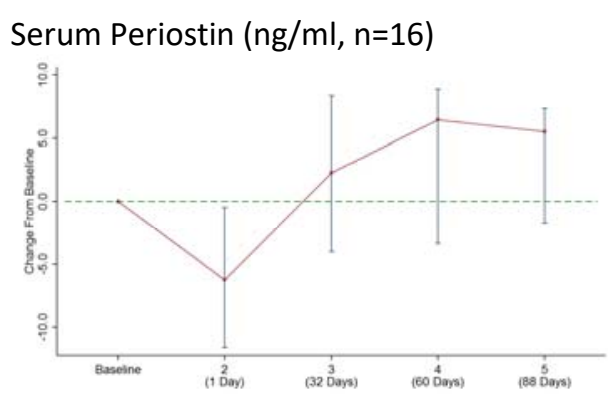

Serum IL-13 Concentration (pg/ml, n=17)

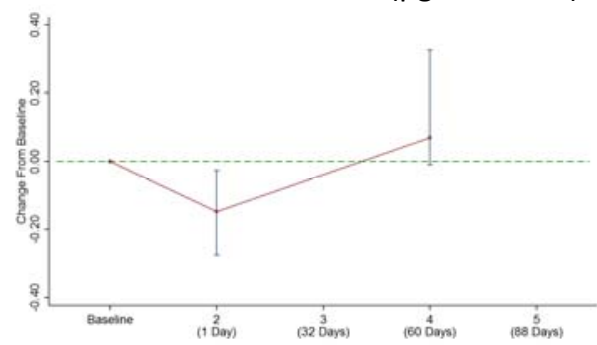

$\mathrm{FEV}_{1}(\%$ predicted, $\mathrm{n}=16)$

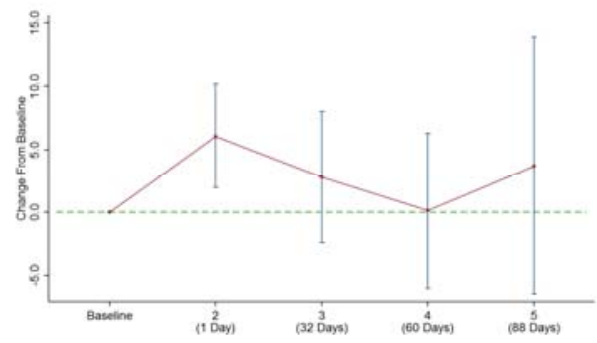



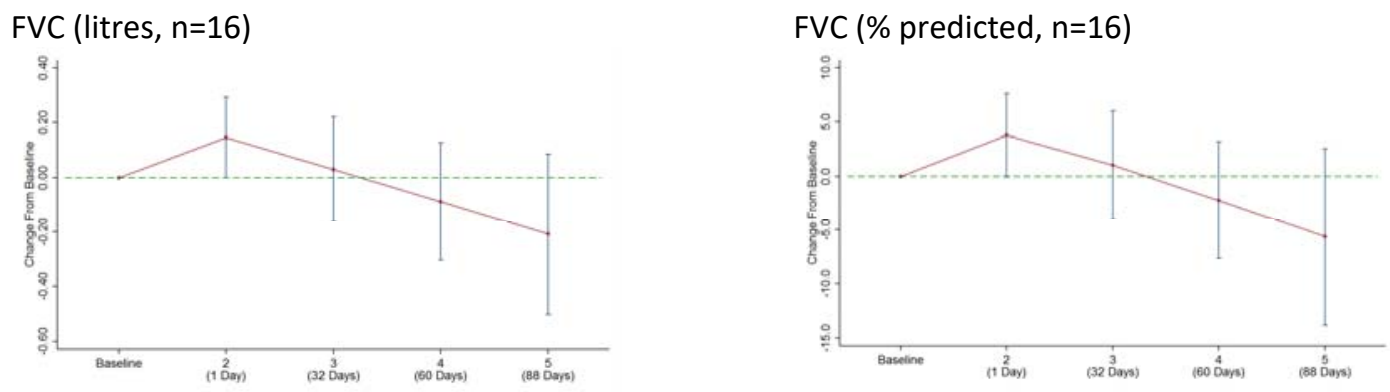

Patient reported outcomes

ACQ Score $(n=17)$

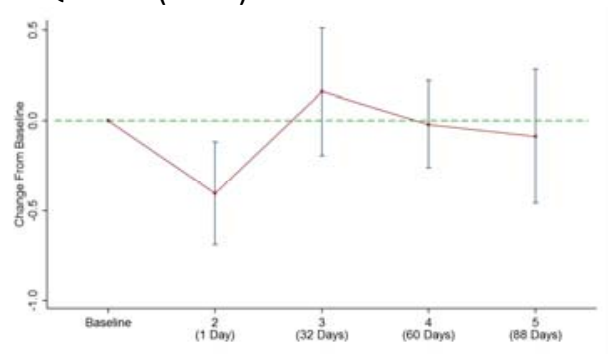

AQLQ Score $(n=17)$

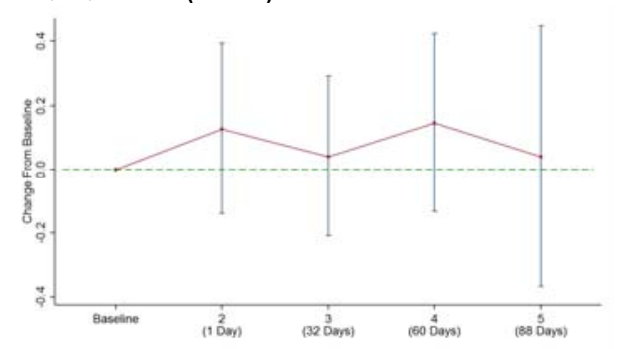




\section{Online Supplement}

\section{Study inclusion and exclusion criteria}

\section{Inclusion Criteria}

Patients must meet the following criteria for study entry:

1. Able and willing to provide written informed consent and to comply with the study procedures.

2. For patients considered to be minors according to national legislation in each country, the written consent of the parent or legal guardian must be obtained, as well as the assent of the minor according to his or her capacity to understand the information provided. Patients within the specified age range who are not legally considered to be minors according to national legislation must consent in their own right. Patients enrolled as minors who attain legal adulthood during the course of the study must consent in their own right at that time

\section{Age $\geq 12$ to $\leq 75$ years at the time of informed consent}

4. Severe asthma (as defined by GINA step 5 classification of asthma severity) after a detailed systematic assessment (the BTS UK Difficult Asthma Network assessment model [Heaney et al 2010] or equivalent) and follow-up by an asthma specialist for at least six months

5. History of asthma treatment with high-doses of ICS $(\geq 1500 \mu \mathrm{g}$ beclomethasone dipropionate daily, or equivalent) and LABAs, with or without an additional controller, for at least six months before Screening

6. Chronic treatment with maintenance OCS for at least six months before the time of informed consent with treatment during the last 28 days being within the following ranges:

a. $\pm 2.5 \mathrm{mg} /$ day daily dose equivalent for patients within the range of 10 to $20 \mathrm{mg} /$ day (range 5 to 20 $\mathrm{mg}$ for adolescents)

b. $\pm 5 \mathrm{mg} /$ day daily dose equivalent for patients within the range of 21 to $40 \mathrm{mg} /$ day

7. Baseline OCS dose as follows:

a. Adults: 10 to $40 \mathrm{mg} / \mathrm{day}$

b. Adolescents: 5 to $40 \mathrm{mg} /$ day daily dose equivalent

8. Compliance with OCS therapy will be based on prior detectable levels of serum prednisolone, cortisol suppression, or observation of Cushingoid appearance consistent with regular systemic steroid use

9. Prior assessment within the six months before the time of informed consent is obtained according to the assessment model of the BTS UK Difficult Asthma Network or equivalent to ensure a diagnosis of refractory asthma with OCS dependence on minimal effective or maximum tolerated dose, defined as follows: 
- Patient has 'uncontrolled' asthma and has detectable serum prednisolone or undetectable cortisol. 'uncontrolled' asthma is defined by any of the following:
o ACQ-7 $>1.25$ or
o Persistent blood eosinophil count $(>0.4 \times 109 / \mathrm{mL})$ or
o Persistent sputum eosinophilia ( $>3 \%)$ or
0 Recurrent exacerbations requiring a boost in steroid dose

Note: Patients who do not meet the 'uncontrolled' asthma criteria listed previously will be defined as 'controlled'

- Patient has 'controlled' asthma and has documented evidence of previous failed OCS downtitration

Note: For patients who are controlled with no documented evidence of failed OCS down-titration, OCS dose optimisation will take place within the context of the BTS (or equivalent) standardised protocols before considering the patient for Screening (considered standard of care for optimisation daily steroid use). During this process, the OCS dose will be reduced at weekly intervals in predefined steps until either of the following criteria for OCS down-titration failure is met:

- Forced expiratory volume in 1 second (FEV1) $<80 \%$ of the patient's personal best value while on the current OCS dose, or

- Increase in 24-hour asthma symptoms, night-time awakenings, or SABA use

10. Chest x-ray or computed tomography (CT) scan obtained within the 12 months before the time of informed consent or chest $x$-ray during the screening period confirming the absence of other significant lung disease ( at the discretion of the investigator. For example a degree of co-morbid bronchiectasis is common in this population and would not exclude them. Severe forms of comorbid diseases such as emphysema and clinically significant bronchiectasis should be excluded. All cases of doubt should be discussed with the medical monitor)

11. Documented history of bronchodilator reversibility response of $\geq 12 \%$ and $\geq 200 \mathrm{~mL}$ within the past 12 months before the time of informed consent, as demonstrated by any of the following:

- Documented airflow obstruction (FEV1/forced vital capacity $[F V C]<70 \%$ ), where FEV1 has varied by $\geq 12 \%$ either spontaneously or in response to OCS therapy, or

- A decrease of $20 \%$ in FEV1 (PC20) in response to methacholine or histamine challenge at $<8$ $\mathrm{mg} / \mathrm{mL}$, indicating the presence of airway hyperresponsiveness, or

- Change in FEV1 by $\geq 12 \%$ and $\geq 200 \mathrm{~mL}$ after acute reversibility testing with $400 \mu \mathrm{g}$ salbutamol via metered dose inhaler (via spacer) or 2.5 to $5 \mathrm{mg}$ nebulised salbutamol. (This assessment 
can be undertaken during the screening period if an assessment has not been performed within the 12 months before the time of informed consent).

\section{Exclusion Criteria}

Patients who meet any of the following criteria will be excluded from study entry:

1. Baseline FEV1 $\leq 39 \%$ of predicted

2. Asthma exacerbation (as described in Section 4.2.6.5) within 28 days before the time of informed consent or during Screening

3. Major episode of infection requiring any of the following:

a. Admission to hospital for $\geq 24$ hours within the 28 days before the time of informed consent or during Screening

b. Treatment with intravenous antibiotics within the 28 days before the time of informed consent or during Screening

c. Treatment with oral antibiotics within the 14 days before the time of informed consent or during Screening

4. Active parasitic infection or Listeria monocytogenes infection within the 6 months before the time of informed consent

5. For adults: Active tuberculosis (TB) requiring treatment within the 12 months before the time of informed consent (patients are also required to have no recurrence of symptoms in the 12 months following completion of TB treatment), or For adolescents: History of active TB requiring treatment

6. Known history of severe clinically significant immunodeficiency, including, but not limited to, human immunodeficiency virus infection and/or currently receiving or have historically received intravenous Ig for treatment for immunodeficiency Note: Immunodeficiency encompasses a wide spectrum of human conditions and/or diseases. A relative IgG deficiency that is thought, but not proven, to be a feature of severe asthma would not be exclusionary for the study. All cases of doubt should be discussed with the medical monitor 7. Evidence of acute or chronic hepatitis or known liver cirrhosis

8. Aspartate aminotransferase (AST) and/or alanine aminotransferase (ALT) and/or total bilirubin elevation $\geq 2.0$ the upper limit of normal (ULN)

9. Diagnosis or history of malignancy, or current investigation for possible malignancy

10. Other clinically significant medical disease that is uncontrolled despite treatment or that is likely, in the opinion of the investigator, to require a change in therapy or affect the ability to participate in the study 
11. History of alcohol, drug, or chemical abuse that would impair or risk the patient's full participation in the study, in the opinion of the investigator

12. Current smoker or former smoker with a smoking history of $>15$ pack-years

A current smoker is defined as someone who has smoked one or more cigarettes per day (or marijuana or pipe or cigar) for $\geq 30$ days within the 24 months before the time of informed consent and for whom cotinine testing is positive.

A former smoker is defined as someone who has smoked one or more cigarettes per day (or marijuana or pipe or cigar) for $\geq 30$ days in his or her lifetime (as long as the 30 -day total did not include the 24 months before the time of informed consent) and for whom cotinine testing is negative.

A pack-year is defined as the average number of packs per day times the number of years of smoking.

13. Current use of an immunomodulatory/immunosuppressive therapy or past use within three months or five drug half-lives (whichever is longer) before the time of informed consent

14. Use of a biologic therapy (including omalizumab) at any time during the 4 months before the time of informed consent

15. History of anaphylaxis with omalizumab treatment or history of anaphylaxis to any therapeutic biological agent

16. Use of zileuton or roflumilast at any time during the two months before the time of informed consent

17. Initiation of or change in allergen immunotherapy within three months before the time of informed consent

18. Treatment with an investigational agent within 30 days of informed consent or 5 half-lives of the investigational agent, whichever is longer

19. Receipt of a live/attenuated vaccine within the 28 days before the time of informed consent, or anticipation of the receipt of live/attenuated vaccine throughout the study

20. Female patients of reproductive potential who are not willing to use a highly effective method of contraception (e.g. contraceptive pill or transdermal patch, spermicide and barrier [condoms], intrauterine device, implants for contraception, injections for contraception [with prolonged release], hormonal vaginal device, sterilisation, surgical tubal ligation, hysterectomy, or true abstinence [in adolescent patients only]) for the duration of the study

21. Female patients who are pregnant or lactating

22. Body mass index (BMI) (mass $[\mathrm{kg}] /$ height $[\mathrm{m}] 2$ ) $>38 \mathrm{~kg} / \mathrm{m} 2$

23. Body weight $<40 \mathrm{~kg}$ 
Table e1: Schedule of study assessments

\begin{tabular}{lccccc}
\hline & Baseline & Visit 2 & Visit 3 & Visit 4 & Visit 5 \\
\hline Demographics & $\mathrm{X}$ & & & & \\
Asthma History & $\mathrm{X}$ & & & & \\
Asthma Medication & $\mathrm{X}$ & $\mathrm{X}$ & $\mathrm{X}$ & $\mathrm{X}$ & $\mathrm{X}$ \\
Lung Function & $\mathrm{X}$ & $\mathrm{X}$ & $\mathrm{X}$ & $\mathrm{X}$ & $\mathrm{X}$ \\
Patient reported outcomes & $\mathrm{X}$ & $\mathrm{X}$ & $\mathrm{X}$ & $\mathrm{X}$ & $\mathrm{X}$ \\
Type-2 Biomarkers & $\mathrm{X}$ & $\mathrm{X}$ & $\mathrm{X}$ & $\mathrm{X}$ & $\mathrm{X}$ \\
Type-2 Cytokines & $\mathrm{X}$ & $\mathrm{X}$ & & $\mathrm{X}$ & \\
\hline
\end{tabular}


Table e2: Technical details of serum IL-5 and IL-13 assays

\begin{tabular}{|c|c|c|}
\hline & IL-5 & IL-13 \\
\hline Assay platform & Simoa Quanterix & IMPACT (immunoassay) \\
\hline Performed by & RBN Myriad & Microcoat \\
\hline LLOQ & $0.05 \mathrm{pg} / \mathrm{ml}$ & $0.014 \mathrm{pg} / \mathrm{ml}$ \\
\hline Dynamic range & $0.012-60 \mathrm{pg} / \mathrm{ml}$ & $0.014-2000 \mathrm{pg} / \mathrm{ml}$ \\
\hline Validation & $\begin{array}{l}\text { LOD, LLOQ, ULOQ, dynamic range } \\
\text { Precision, linearity, spike recovery, (3x freeze/thaw) } \\
\text { No interference with IL-5Ra } \\
\text { Assay stability in plasma/serum } \\
\text { Specificity } \\
\text { Minimal interference in asthma, COPD serum matrices }\end{array}$ & $\begin{array}{l}\text { Developed by Roche Diagnostics. Uses lebrikizumab as the capture } \\
\text { antibody. } \\
\text { Details on optimization published (see below) }\end{array}$ \\
\hline Description & assay detect total human IL-5 & assay detects IL-13 \\
\hline Reference & Validation done by RBM Myriad for Genentech & $\begin{array}{l}\text { Cai, F., Hornauer, H., Peng, K., Schofield, C. A., Scheerens, H., \& Morimoto, } \\
\text { A. M. (2016). Bioanalytical challenges and improved detection of } \\
\text { circulating levels of IL-13. Bioanalysis, } 8(4), 323-332 \text {. }\end{array}$ \\
\hline
\end{tabular}


Figure e1: Study flow diagram and patient numbers

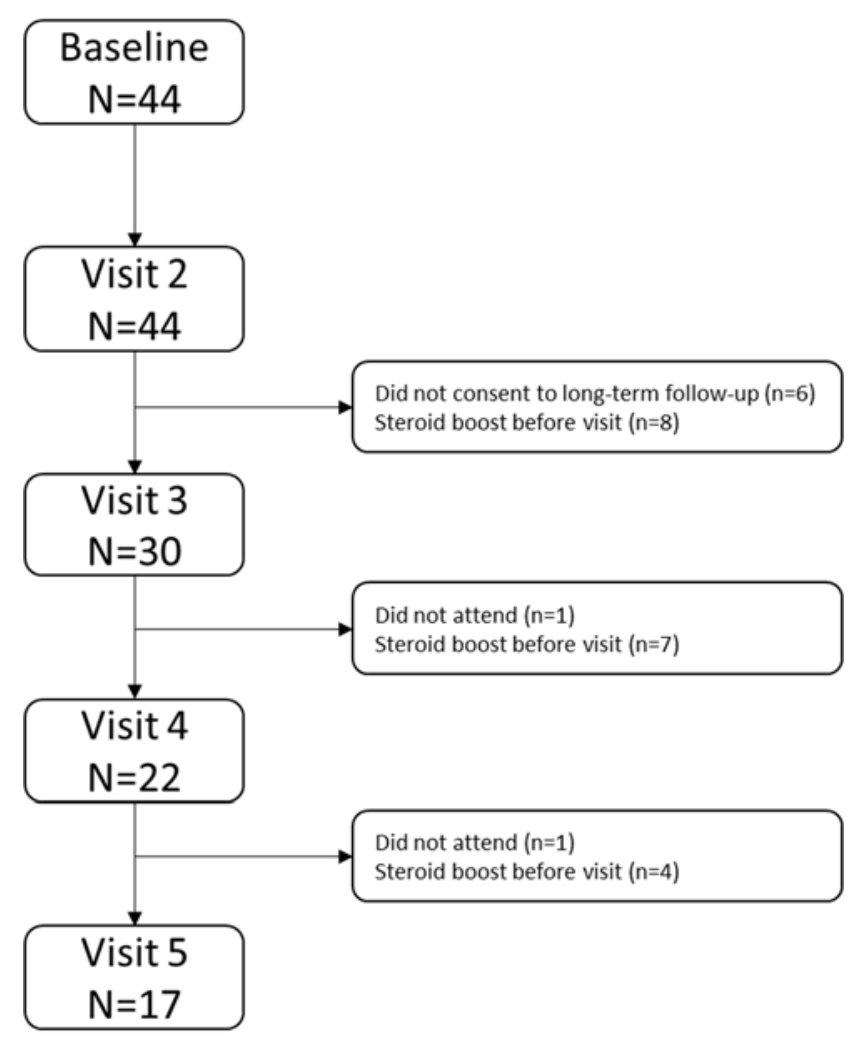


Figure e2: Trajectories of type-2 biomarkers and cytokines, patient reported outcomes (ACQ-7 and $A Q L Q$ ) and lung function ( $\mathrm{FEV}_{1}$ and $\mathrm{FVC}$ ) over serial study visits - subjects with missing data at any short-term visit, or who required additional rescue corticosteroids for exacerbation in addition to the high-dose OCS between baseline visit and study 2 were excluded. Data are shown as median or mean difference (with $95 \%$ confidence intervals) as appropriate.

\section{Type-2 Biomarkers}

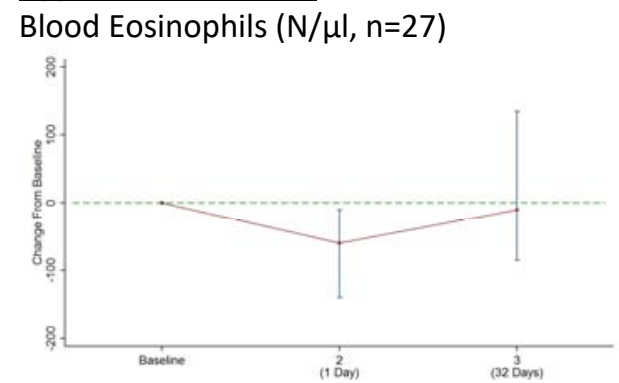

FeNO (ppb, $n=27)$

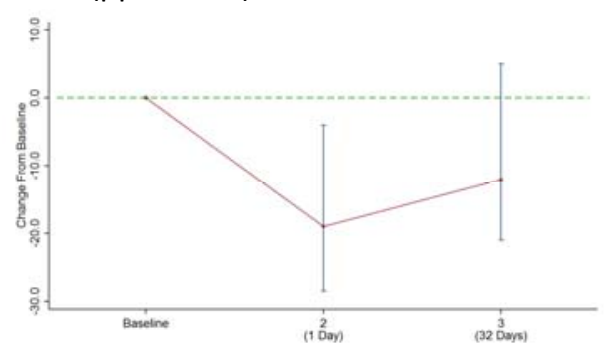

Type-2 Cytokines

IL-5 Concentration ( $\mathrm{pg} / \mathrm{ml}, \mathrm{n}=18$ )

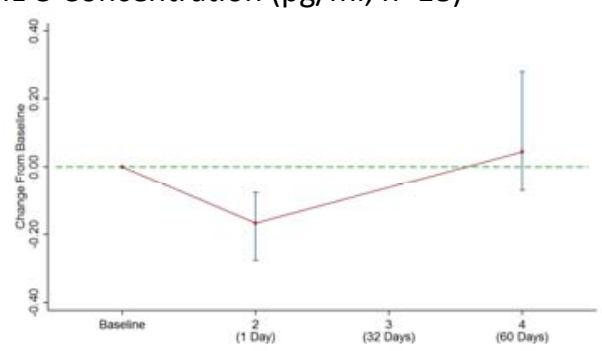

\section{Lung Function}

$\mathrm{FEV}_{1}$ (litres, $\mathrm{n}=28$ )

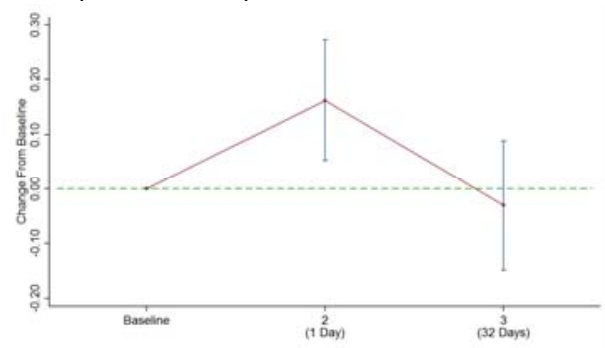

FVC (litres, $n=28$ )

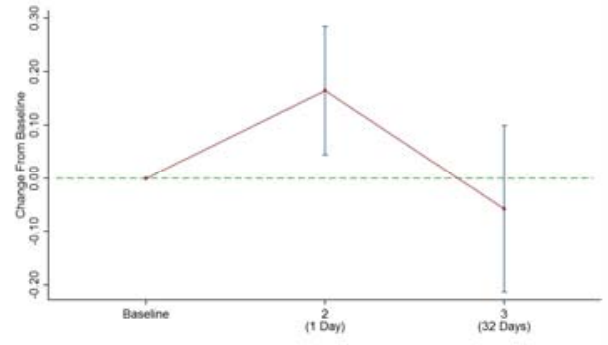

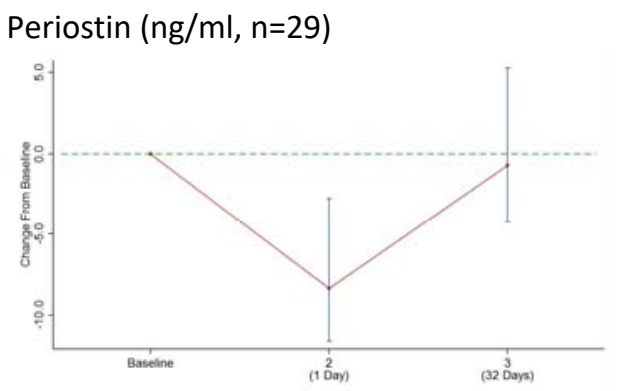
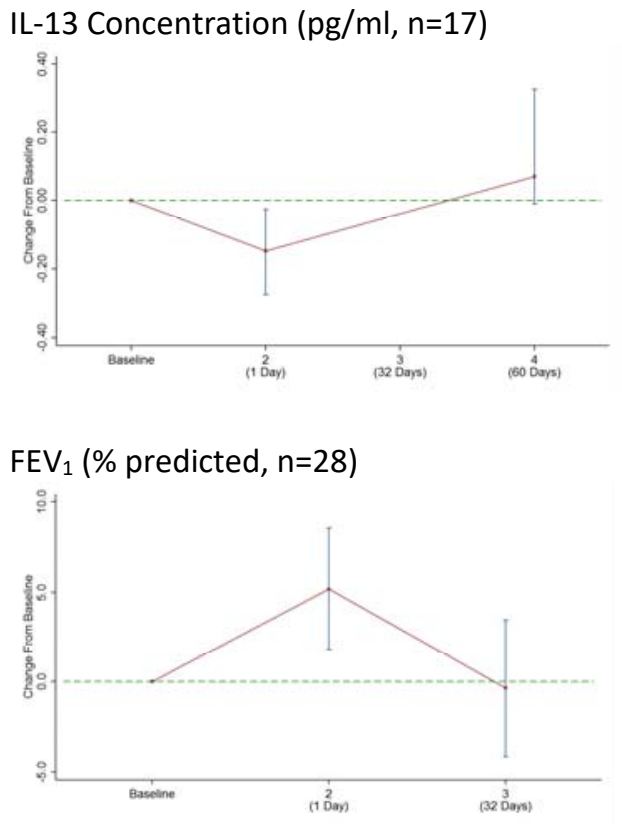

FVC ((\% predicted, $\mathrm{n}=28$ )

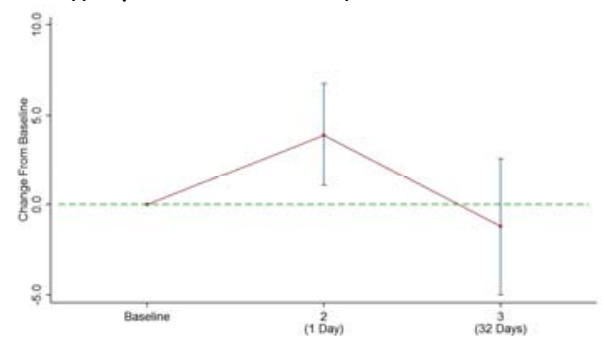




\section{Patient reported outcomes}

ACQ Score $(n=30)$

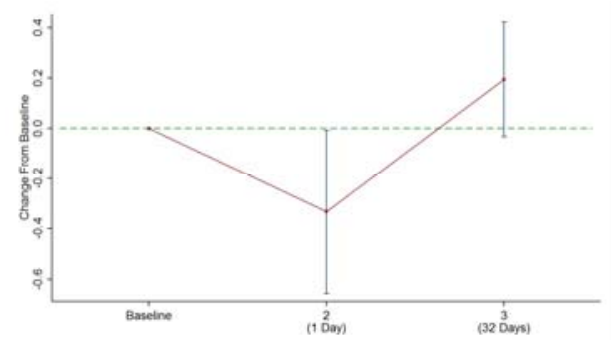

AQLQ Score $(n=30)$

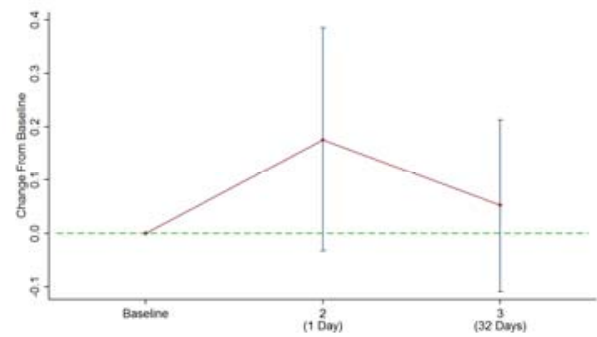


Table e3: Long-term change in type-2 biomarkers and cytokines, lung function (FEV 1 and FVC) and patient reported outcomes (ACQ and AQLQ) over serial study visits - subjects who required additional rescue corticosteroids for exacerbation in addition to the study intervention were excluded. Data are shown as median (IQR) or mean (SD) as appropriate.

\begin{tabular}{|c|c|c|c|c|c|c|c|c|c|c|c|c|c|}
\hline & \multicolumn{3}{|c|}{ Baseline } & \multicolumn{4}{|c|}{ Visit 2 (1 day post-intervention) } & \multicolumn{3}{|c|}{ Visit 3 (32 days post-intervention) } & \multicolumn{3}{|c|}{ Visit 4 (60 days post-intervention) } \\
\hline & Count & \multicolumn{2}{|c|}{$\begin{array}{l}\text { Absolute } \\
\text { Value }\end{array}$} & \multicolumn{2}{|c|}{$\begin{array}{l}\text { Absolute } \\
\text { Value }\end{array}$} & $\begin{array}{c}\text { Difference } \\
(95 \% \mathrm{Cl})\end{array}$ & $\begin{array}{c}\text { P- } \\
\text { value }\end{array}$ & $\begin{array}{l}\text { Absolute } \\
\text { Value }\end{array}$ & $\begin{array}{c}\text { Difference } \\
(95 \% \mathrm{Cl})\end{array}$ & $\begin{array}{c}\text { P- } \\
\text { value }\end{array}$ & $\begin{array}{l}\text { Absolute } \\
\text { Value }\end{array}$ & $\begin{array}{c}\text { Difference } \\
(95 \% \mathrm{Cl})\end{array}$ & $\begin{array}{c}\mathrm{P}- \\
\text { value }\end{array}$ \\
\hline \multicolumn{14}{|l|}{ Type-2 Biomarkers } \\
\hline Blood Eosinophils $(\mathrm{N} / \mathrm{ul})^{\mathrm{a}}$ & 14 & \multicolumn{2}{|c|}{$180(150,260)$} & \multicolumn{2}{|c|}{$120(100,160)$} & $-60(-140,-15)$ & 0.022 & $170(110,270)$ & $-10(-115,100)$ & 0.975 & $160(120,250)$ & $-20(-70,20)$ & 0.753 \\
\hline Periostin $(\mathrm{ng} / \mathrm{ml})^{\mathrm{a}}$ & 16 & \multicolumn{2}{|c|}{$46.4(38.4,61.2)$} & \multicolumn{2}{|c|}{$40.2(36.2,52.9)$} & $-6.2(-11.6,-0.5)$ & 0.002 & $48.7(43.9,59.2)$ & $2.3(-4.0,8.3)$ & 0.278 & $52.8(42.2,57.9)$ & $6.4(-3.3,8.8)$ & 0.352 \\
\hline $\mathrm{FeNO}(\mathrm{ppb})^{\mathrm{a}}$ & 13 & \multicolumn{2}{|c|}{$37.7(25.0,59.0)$} & \multicolumn{2}{|c|}{$29.0(17.0,35.0)$} & $-8.7(-29.0,2.0)$ & 0.014 & $34.0(25.0,40.0)$ & $-3.7(-22.5,9.0)$ & 0.152 & $28.0(23.0,63.0)$ & $-9.7(-33.5,25.3)$ & 0.624 \\
\hline \multicolumn{14}{|l|}{ Type- 2 Cytokines } \\
\hline IL-5 Concentration $(\mathrm{pg} / \mathrm{ml})^{\mathrm{a}}$ & 18 & \multicolumn{2}{|c|}{$0.22(0.11,0.54)$} & \multicolumn{2}{|c|}{$0.05(0.00,0.14)$} & $-0.17(-0.28,-0.08)$ & 0.002 & & & & $0.27(0.16,0.49)$ & $0.05(-0.07,0.28)$ & 0.913 \\
\hline $\mathrm{IL}-13$ Concentration $(\mathrm{pg} / \mathrm{ml})^{\mathrm{a}}$ & 17 & \multicolumn{2}{|c|}{$0.31(0.19,0.50)$} & \multicolumn{2}{|c|}{$0.16(0.11,0.22)$} & $-0.15(-0.27,-0.03)$ & 0.002 & & & & $0.38(0.32,0.82)$ & $0.07(-0.01,0.33)$ & 0.028 \\
\hline \multicolumn{14}{|l|}{ Lung Function } \\
\hline $\mathrm{FEV}_{1}$ (litres) $^{\mathrm{b}}$ & 16 & \multicolumn{2}{|c|}{$1.86(0.59)$} & \multicolumn{2}{|c|}{$2.04(0.62)$} & $0.18(0.06,0.29)$ & 0.005 & $1.93(0.61)$ & $0.06(-0.09,0.21)$ & 0.379 & $1.85(0.61)$ & $-0.01(-0.20,0.18)$ & 0.912 \\
\hline $\mathrm{FEV}_{1}(\% \text { predicted })^{\mathrm{b}}$ & 16 & \multicolumn{2}{|c|}{$61.9(17.5)$} & \multicolumn{2}{|c|}{$68.0(19.0)$} & $6.1(2.0,10.1)$ & 0.006 & $64.8(20.2)$ & $2.8(-2.4,8.0)$ & 0.270 & $62.1(18.8)$ & $0.1(-6.0,6.3)$ & 0.966 \\
\hline FVC (litres) ${ }^{b}$ & 16 & \multirow{2}{*}{\multicolumn{2}{|c|}{$\begin{array}{l}3.00(0.76) \\
77.9(14.4)\end{array}$}} & \multicolumn{2}{|c|}{$3.15(0.76)$} & $0.15(-0.00,0.29)$ & 0.052 & $3.03(0.71)$ & $0.03(-0.16,0.22)$ & 0.741 & $2.91(0.72)$ & $-0.09(-0.30,0.13)$ & 0.393 \\
\hline FVC (\%predicted) ${ }^{b}$ & 16 & & & $81.7(14$ & & $3.8(-0.1,7.6)$ & 0.054 & 78.9 (14.4) & $1.0(-4.0,6.0)$ & 0.676 & $75.7(13.4)$ & $-2.3(-7.7,3.2)$ & 0.389 \\
\hline Patient reported outcomes & & & & & & & & & & & & & \\
\hline ACQ Score ${ }^{b}$ & 17 & $3.0(1.2)$ & & $2.6(1.3$ & & $-0.4(-0.7,-0.1)$ & 0.009 & $3.2(1.2)$ & $0.2(-0.2,0.5)$ & 0.354 & $3.0(1.3)$ & $-0.0(-0.3,0.2)$ & 0.855 \\
\hline AQLQ Score ${ }^{b}$ & 17 & $3.7(1.5)$ & & $3.9(1$. & & $0.1(-0.1,0.4)$ & 0.328 & $3.8(1.6)$ & $0.0(-0.2,0.3)$ & 0.736 & $3.9(1.7)$ & $0.1(-0.1,0.4)$ & 0.285 \\
\hline & & Visit 5 (88 da & ays pos & st-interventic & & & & & & & & & \\
\hline & & $\begin{array}{l}\text { Absolute } \\
\text { Value }\end{array}$ & & $\begin{array}{l}\text { ifference } \\
95 \% \mathrm{Cl})\end{array}$ & $\begin{array}{c}\mathrm{P}- \\
\text { value }\end{array}$ & & & & & & & & \\
\hline Type-2 Biomarkers & & & & & & & & & & & & & \\
\hline Blood Eosinophils $(\mathrm{N} / \mathrm{ul})^{\mathrm{a}}$ & & $5(130,320)$ & & $(-40,120)$ & 0.875 & & & & & & & & \\
\hline Periostin $(\mathrm{ng} / \mathrm{ml})^{\mathrm{a}}$ & 51.9 & $(40.3,60.8)$ & 5.5 & $(-1.7,7.3)$ & 0.255 & & & & & & & & \\
\hline FeNO $(p p b)^{a}$ & 31.0 & $(16.0,63.0)$ & $-6.7(-$ & $(-35.0,10.0)$ & 0.552 & & & & & & & & \\
\hline Type-2 Cytokines & & & & & & & & & & & & & \\
\hline IL-5 Concentration $(\mathrm{pg} / \mathrm{ml})^{a}$ & & & & & & & & & & & & & \\
\hline IL-13 Concentration (pg/ml) & & & & & & & & & & & & & \\
\hline Lung Function & & & & & & & & & & & & & \\
\hline $\mathrm{FEV}_{1}$ (litres) $^{\mathrm{b}}$ & & $.94(0.65)$ & 0.07( & $(-0.19,0.34)$ & 0.558 & & & & & & & & \\
\hline $\mathrm{FEV}_{1}(\% \text { predicted })^{\mathrm{b}}$ & & $5.6(23.2)$ & 3.7( & $(-6.5,13.8)$ & 0.451 & & & & & & & & \\
\hline FVC (litres) $)^{b}$ & & $.79(0.83)$ & -0.21( & $(-0.50,0.09)$ & 0.152 & & & & & & & & \\
\hline FVC (\%predicted) $)^{b}$ & & $2.3(16.7)$ & -5.6( & $(-13.8,2.5)$ & 0.163 & & & & & & & & \\
\hline Patient Reported Outcomes & & & & & & & & & & & & & \\
\hline ACQ Score ${ }^{b}$ & & $3.0(1.2)$ & -0.1 & $(-0.5,0.3)$ & 0.627 & & & & & & & & \\
\hline AQLQ Score ${ }^{b}$ & & $3.8(1.8)$ & 0.0 & $(-0.4,0.4)$ & 0.836 & & & & & & & & \\
\hline
\end{tabular}

${ }^{a}$ Median (inter-quartile range)

b Mean (standard deviation) 